\title{
PARTICIPATION OF RURAL WOMEN IN FARM AND NON-FARM ACTIVITIES : AN ECONOMIC ANALYSIS
}

\author{
N. Chowdhury ${ }^{1}$, M. H. A. Rashid ${ }^{2}$, S. Ahmed ${ }^{3}$ and A. Sultana ${ }^{4}$ \\ Department of Agricultural Economics, Bangladesh Agricultural University \\ Mymensingh-2202, Bangladesh
}

\begin{abstract}
Rural women are silent workers and major contributors to rural economy. Their economic contributions are often appreciated but not widely recognized. The purpose of the study was to make the participation of rural women in farm and non-farm activities visible and their contribution in generating household income. Data were collected from a purposively-drawn sample of 60 rural households consisting of 20 low, 20 medium and 20 high income households. The obtained data were analyzed by using tabular and statistical techniques. Women of these three categories contributed to Tk. 19398, 24180 and 20917.50 which were 35.18, 25.11 and 14.20 per cent of total household income respectively. It was evident that, female participation of low and medium income households is markedly higher in non-farm activities than the high income households. The results of the study showed clear evidences of greater extent of women's participation in farm and non-farm activities as well as in various household decision making events. The findings of the study suggest that, in order to enhance women participation in farm and non-farm activities and their contribution to household income, the quality and status of support service like input supply, credit facilities, extension and motivation, need-based training should be improved. A successful government and non-government collaborative programme can best address these issues in an integrated manner.
\end{abstract}

Key words : Rural, Women, Farm, Non-farm, Participation

\section{INTRODUCTION}

The economy Bangladesh is predominantly based on agriculture and other activities related to agriculture sector. Hence an overwhelming majority of rural population is mainly dependent on agriculture sector both for its employment and livelihood. At the same time, various non-agricultural activities are also playing an important role in providing the opportunities of employment and incomes to the labour force belonging to both farming and non-farming households.

\footnotetext{
1, 3, 4 Post-graduate students, Department of Agricultural Economics, Bangladesh Agricultural University Mymensingh-2202, Bangladesh

2 Professor, Department of Agricultural Economics, Bangladesh Agricultural University Mymensingh-2202, Bangladesh
} 
The rural economy of Bangladesh has witnessed remarkable structural changes and diversification during the 1990s. The recent statistics show that the proportion of rural households depending on non-farm activities is expanding over time at a faster rate; compared to farm households and that in certain areas the extent of involvement in such activities may be quite high. A second type of change indicates a relative decline in importance of agricultural wage labour, which implies a possible rise in the proportion of households dependent on self-employment or non-farm wage employment.

Present situation of women are much lower in status than that of men. Women represent a half of the country's human resources and thus a half of its potential. Their literacy rate is only 49.8 per cent, much lower than that of men 57.1 per cent, life expectancy is 64.7 years for men and 65.9 years for women (BBS, 2007). Excessive mortality among women due to discrimination has resulted in an uneven sex ratio in the population whereby there are 103.8 men for every 100 women. Nutritional status of women and girls is marked by sharp differences with that of men and boys. As per Labor Force Survey $2005-06$, of the total 49.5 million labor forces, 37.4 million are male and 12.1 million are female.

In Bangladesh, rural woman presents a dismal picture. Socially they do not have individual identity. Women who are struggling hard to earn their livelihood and trying to overcome poverty generally do not get any incentive from the influential people of the locality. In Bangladesh the movement for women's emancipation is going on as a part of the process of social change and not as a revolutionary movement. In the country they worked hard and contributed significantly to agricultural production and family income. Unless the actual and potential contribution of women to the agricultural production process is recognized, efforts to improve the wellbeing of farm household and ensuring food security will be hampered.

In today's society, the role of women extends way beyond the home and bringing- up of children. Women have to perform the dual role of housewife and wage earner. In rural areas, women are engaged in farm operation as cultivators, assistants to male cultivators and agricultural labourers. Women are actively involved in pre-sowing, post-sowing, harvesting, post-harvest operation as well as growing vegetables and fruits mostly for family consumption, care for poultry and livestock, supplement families nutrition and incomes through raising kitchen garden and working in cottage industry, handloom weaving etc. Women belonging to low socio-economic strata are actively engaged in agricultural labour. They also show their involvement in planning, decision making and supervisory activities.

Women participation in home and farm activities is dependent upon social, cultural and economic condition in area. It also varies from region to region and even within a region, their involvement varies widely among different farming system, castes, classes and socio-economic status (Kada and Kada, 1985). In spite of several restrictions, women of the low income households are found working outside their home due to severe economic pressures, while women of the medium and high income household seek employment in order to decrease self dependency and to increase the standard of living. 
The pace of development in any country largely depends upon the people's participation including women. In Bangladesh women constitute almost half of the population. Under the circumstances, this study has been undertaken to explore women's income level and participation in farm and non-farm activities, their contributions to agricultural and household decisions with the following specific objectives.

\section{Objectives}

i. to assess the nature and extent of involvement of rural women in farm and non-farm activities;

ii. to estimate contribution of rural women to household income; and

iii. to evaluate the contribution of rural women in household decision making process.

\section{MATERIALS AND METHODS}

The study was carried out in two villages namely Unia Para and Kala Para under Mymensingh sadar upazila of Mymensingh district. Data were collected from purposively-drawn sample of 60 households consisting of 20 low, 20 medium and 20 large income households. The households were categorized according to the level of family income as below.

1) Low income households i.e; Annual income less than Tk. 55,000.00

2) Medium income households i.e; Annual income ranging between Tk. 55,000.00 to Tk. $100,000.00$ and

3) High income households i.e.; Annual income more than Tk. 100,000.00

Both tabular and statistical techniques were used for the analysis of the data.

The annual income was measured in Taka. The following equation was used to calculate annual income-

$\mathrm{Y}=\sum_{i=1}^{n} A i+\sum_{i=1}^{n} B i$

$\mathrm{Y}=$ Annual income $(\mathrm{Tk}), \mathrm{Ai}=$ Annual total income (male + female) from $\mathrm{i}^{\text {th }}$ farm activities, $\mathrm{Bi}=$ Annual total income (male + female) from $\mathrm{i}^{\text {th }}$ non-farm activities,

$\mathrm{i}=1,2,3, \ldots \mathrm{n}$

\section{Participation index of decision making process}

To assess the level of participation of rural women in farm, non-farm and household decisions, the participation index was used. The scores given for different levels of participation in decision making are: (i) if other than husband and wife take the decisions, (ii) if the decision is taken by husband alone, (iii) if the decision is taken jointly by the husband and wife and (iv) if the decision is taken by the wife alone. The Participation Index (PI) was calculated by using the following formula. 
Participation Index (PI) for each decision making process :

$$
\begin{aligned}
\mathrm{PI} & =\sum \mathrm{W}_{\mathrm{i}} \mathrm{X}_{\mathrm{i}} \\
& =\mathrm{W}_{1} \mathrm{X}_{1}+\mathrm{W}_{2} \mathrm{X}_{2}+\mathrm{W}_{3} \mathrm{X}_{3}+\mathrm{W}_{4} \mathrm{X}_{4}
\end{aligned}
$$

Where,

PI = participation index of the $\mathrm{i}^{\text {th }}$ decision

$\mathrm{X}_{1}=$ decisions that are taken by others

$\mathrm{X}_{2}=$ decision that are taken by husband

$X_{3}=$ decision that are taken jointly by husband and wife

$\mathrm{X}_{4}=$ decisions that are taken by wife herself

$\mathrm{W}_{\mathrm{i}}=$ weightage

$\mathrm{i}=1,2,3,4$

Participation index of each decisions could range from 0 to 400 , where 0 indicating no freedom and 400 indicating perfect (full) freedom of wives. For clear understanding the participation index was converted into percentage using the maximum possible participation index of 400 as 100 percent.

\section{RESULTS AND DISCUSSION}

The average annual income of low, medium and high income households stood at Tk. 54878.25, 96279.65.00 and 147260 respectively. Women of these three categories contributed Tk. 19398, 24180 and 20917.50 which were 35.18, 25.11 and 14.20 per cent of total household income respectively (Table 1). On the other hand, the expenditure incurred in low, medium and high income households were Tk. 48490, 81250 and 112200, respectively.

Table 1. Contribution of women to total family income in low, medium and high income households

\begin{tabular}{l|c|c|c}
\hline $\begin{array}{c}\text { Categories of } \\
\text { households }\end{array}$ & $\begin{array}{c}\text { Average annual } \\
\text { family income }(\mathrm{Tk})\end{array}$ & $\begin{array}{c}\text { Earning of women } \\
\text { (Tk/year) }\end{array}$ & $\begin{array}{c}\text { Per cent contribution } \\
\text { to total income }\end{array}$ \\
\hline Low income & 54878.25 & 19398.5 & 35.18 \\
Medium income & 96279.65 & 24180 & 25.11 \\
High income & 147260 & 20917.5 & 14.20 \\
\hline
\end{tabular}

Source : Chowdhury, 2009

But women participation in non-farm activities was higher in low income households (85.87 per cent) that in medium income (53.83 per cent) and high income households (45.26 per cent) (Table 2). On the other hand, male participation in farm activities was higher in high income households (53.52 per cent) compared to low and medium income household. From the finding, it can be inferred that the rural women are fighting back with non-farm activities for the improvement of their livelihoods. 
Table 2. Farm and non- farm activities of three categories of households

\begin{tabular}{l|ccc|c|c}
\hline \multirow{2}{*}{ Households } & \multicolumn{2}{|c|}{ Farm activities } & \multicolumn{2}{c}{ Non-farm activities } \\
\cline { 2 - 5 } & \% of men & \% of women & \% of men & \% of women \\
\hline Low income households & 25.26 & 14.63 & 74.72 & 85.87 \\
Medium income households & 23.45 & 45.86 & 76.39 & 53.83 \\
High income households & 53.52 & 51.73 & 46.48 & 45.26 \\
\hline
\end{tabular}

Source : Chowdhury, 2009

Table 3. Women's participation in farm decision of low, medium and high income households

\begin{tabular}{|c|c|c|c|c|c|c|c|c|c|c|c|c|c|c|c|}
\hline \multirow{3}{*}{$\begin{array}{l}\text { Decision making } \\
\text { process }\end{array}$} & \multicolumn{5}{|c|}{ Low income } & \multicolumn{5}{|c|}{ Medium income } & \multicolumn{5}{|c|}{ High income } \\
\hline & \multicolumn{4}{|c|}{$\begin{array}{c}\text { Degree of } \\
\text { participation } \\
\text { (No. of responses) }\end{array}$} & \multirow{2}{*}{ 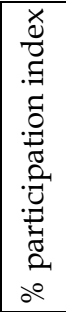 } & \multicolumn{4}{|c|}{$\begin{array}{c}\text { Degree of } \\
\text { participation } \\
\text { (No. of responses) }\end{array}$} & \multirow{2}{*}{ 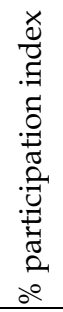 } & \multicolumn{4}{|c|}{$\begin{array}{c}\text { Degree of } \\
\text { participation } \\
\text { (No. of responses) }\end{array}$} & \multirow{2}{*}{ 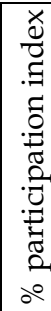 } \\
\hline & 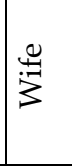 & 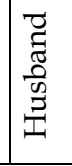 & ص & 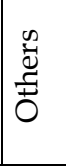 & & $\stackrel{\leftrightarrow}{: \rightarrow}_{3}^{0}$ & 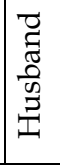 & 壱 & $\frac{n}{0}$ & & $\stackrel{0}{i=1}$ & 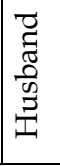 & ص & 苞 & \\
\hline $\begin{array}{l}\text { Choice of c } \\
\text { grown }\end{array}$ & 1 & 12 & 3 & 4 & 66 & 4 & 10 & 6 & - & 6 & 8 & 9 & 2 & 1 & 71 \\
\hline Post harvest operation & 16 & 2 & 2 & - & 93 & 8 & 7 & 3 & 2 & 72 & 16 & 2 & 1 & - & 89 \\
\hline $\begin{array}{l}\text { Buying and selling of } \\
\text { real estate }\end{array}$ & 1 & 16 & 1 & 2 & 54 & 3 & 7 & 7 & 3 & 63 & 7 & 4 & 7 & 2 & 73 \\
\hline $\begin{array}{l}\text { Buy and sell of } \\
\text { agricultural product }\end{array}$ & 1 & 19 & - & - & 53 & 6 & 6 & 6 & 2 & 70 & 7 & 4 & 7 & 2 & 73 \\
\hline Homestead gardening & 15 & 2 & 3 & & 91 & 7 & 8 & 5 & & 74 & 15 & 3 & 2 & - & 90 \\
\hline $\begin{array}{l}\text { Livestock and -poultry } \\
\text { rearing }\end{array}$ & 18 & 1 & 1 & - & 96 & 10 & - & 10 & - & 88 & 12 & 2 & 6 & - & 87 \\
\hline $\begin{array}{l}\text { Fishery/aquaculture } \\
\text { operation }\end{array}$ & 1 & 13 & 4 & 2 & 55 & 5 & 7 & 6 & 2 & 68 & 7 & 6 & 4 & 2 & 68 \\
\hline $\begin{array}{l}\text { Purchase of } \\
\text { agricultural equipment }\end{array}$ & 6 & 8 & 4 & 2 & 68 & 3 & 7 & 7 & 3 & 63 & 4 & 6 & 6 & 4 & 63 \\
\hline Repairing equipment & 5 & 5 & 5 & 5 & 62 & 4 & 9 & 5 & 2 & 64 & 6 & 6 & 8 & & 73 \\
\hline All decision matters & 64 & 79 & 23 & 16 & 69 & 50 & 61 & 55 & 14 & 70 & 82 & 42 & 31 & 11 & 78 \\
\hline
\end{tabular}

Source : Chowdhury, 2009

It was found that women had participated in different types of household decisions; but in some aspects their rights to make decision was suppressed by the dominance of men. Women's participation rates in making decisions regarding farm activities were estimated at 69, 70 and 78 per cent in low, medium and high income households, respectively. Women's participation rates for homestead gardening and livestock and poultry rearing and post harvest operation stood at 91 and 96 and 93 per cent in low income households and 74 and 88 and 72 per cent in medium income households and 90 
and 87 and 89 per cent in high income households respectively (Table 3). Women's participation rates in deciding real estate purchase and sale were estimated at 54,63 and 73 per cent in low, medium and high income households, respectively. Thus it was evident that women had relatively higher freedom in making farm decisions regarding post harvest operations, homestead gardening and rearing livestock and poultry. The relatively higher level of freedom in such decisions may be due to the fact that these jobs were mostly done by women. The overall women's participation rate in family and social affair decisions was higher in high income households (80 per cent) than in medium (76 per cent) and low income households (71 per cent), respectively (Table 4). The variation in women's participation rates was not much different for the decisions like child care, marriage, education children and participating NGOs.

Table 4. Women's role in making decisions regarding family and social affairs

\begin{tabular}{|c|c|c|c|c|c|c|c|c|c|c|c|c|c|c|c|}
\hline \multirow{3}{*}{$\begin{array}{l}\text { Decision making } \\
\text { process }\end{array}$} & \multicolumn{5}{|c|}{ Low income } & \multicolumn{5}{|c|}{ Medium income } & \multicolumn{5}{|c|}{ High income } \\
\hline & \multicolumn{4}{|c|}{$\begin{array}{l}\text { Degree of } \\
\text { participation } \\
\text { (No. of } \\
\text { responses) }\end{array}$} & \multirow{2}{*}{ 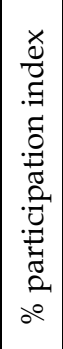 } & \multicolumn{4}{|c|}{$\begin{array}{c}\text { Degree of } \\
\text { participation (No. of } \\
\text { responses) }\end{array}$} & \multirow{2}{*}{ 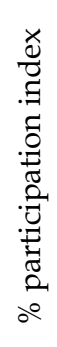 } & \multicolumn{4}{|c|}{$\begin{array}{l}\text { Degree of } \\
\text { participation } \\
\text { (No. of } \\
\text { responses) }\end{array}$} & \multirow{2}{*}{ 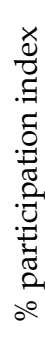 } \\
\hline & $\stackrel{\varphi}{\rightarrow}$ & 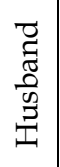 & $\stackrel{5}{\circ}$ & $\begin{array}{l}\stackrel{n}{4} \\
\stackrel{5}{0}\end{array}$ & & 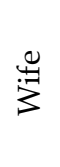 & 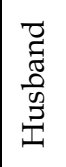 & 㫄 & 离 & & 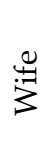 & 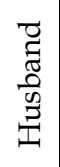 & 营 & $\frac{n}{\stackrel{0}{0}}$ & \\
\hline $\begin{array}{l}\text { Expenditure on family } \\
\text { maintenance }\end{array}$ & 4 & 10 & 6 & - & 67 & 10 & 8 & 2 & - & 78 & 8 & 4 & 8 & - & 80 \\
\hline $\begin{array}{l}\text { Joining social ceremonies } \\
\text { or visiting relatives }\end{array}$ & 8 & 7 & 3 & 2 & 68 & 10 & 8 & 2 & - & 78 & 7 & 4 & 8 & 1 & 76 \\
\hline Borrowing of money & - & - & 12 & 8 & 55 & 12 & 5 & 2 & 1 & 82 & 10 & 5 & 5 & - & 81 \\
\hline Family planning & 5 & & 15 & & 81 & & & 10 & 10 & 50 & & & 15 & 5 & 63 \\
\hline $\begin{array}{l}\text { Marriage of sons and } \\
\text { daughters }\end{array}$ & 8 & 6 & 6 & - & 77 & 11 & 6 & 2 & 1 & 79 & 6 & 4 & 10 & - & 78 \\
\hline $\begin{array}{l}\text { Education of sons and } \\
\text { daughters }\end{array}$ & 8 & 6 & 6 & - & 77 & 9 & 6 & 3 & 2 & 74 & 8 & 2 & 10 & - & 82 \\
\hline Childcare & 16 & - & 4 & - & 96 & 16 & - & 4 & - & 95 & 16 & - & 4 & - & 95 \\
\hline To give a vote & 10 & 10 & - & - & 75 & 10 & 10 & - & - & 75 & 10 & 10 & - & - & 75 \\
\hline Participating NGO's & 10 & - & 5 & 5 & 75 & 12 & 2 & 2 & 4 & 78 & 11 & 3 & 2 & 4 & 75 \\
\hline Repairing house & 4 & 8 & 4 & 4 & 60 & 8 & 6 & 6 & - & 78 & 7 & 8 & 3 & 2 & 68 \\
\hline All decision matters & 68 & 47 & 46 & 19 & 71 & 98 & 51 & 31 & 18 & 76 & 83 & 40 & 65 & 12 & 80 \\
\hline
\end{tabular}

\section{CONCLUSIONS}

Women are good partners of the socio-economic development of the country in general and the family in particular. They can contribute significantly to the socio-economic upliftment of the family if proper environment with facilities can be ensured. The analysis 
shows that women play an important role in farm activities especially in post-harvest operations, homestead gardening and livestock and poultry rearing. Economic pressure is forcing them to break away their traditional roles of housewives into farm or non-farm labourers. The finding of the present study reveals that contribution of female labour in different activities as well as in total family income was substantial. This was particularly true for low income households.

\section{REFERENCES}

BBS, 2007. Statistical Yearbook for Bangladesh. Bangladesh Bureau of Statistics, Statistics Division, Ministry of Planning, Government of the People's Republic of Bangladesh, Dhaka.

Chowdhury, N. 2009. Participation of rural women in farm and non-farm activities: An Economic Analysis. M. Sc. Thesis, Department of Agricultural Economics, Bangladesh Agricultural University, Mymensingh.

Kada, R. and Kada, Y. 1985. The Changing Role of Women in Japanese Agriculture : The Impact of New Rice Technology Women's Employment, Women in Rice Farming, IRRI, Los Banos, Laguna, Philippines. 